\title{
HOAX VERSUS FREEDOM OF SPEECH (IN THE PERSPECTIVE OF PANCASILA)
}

\author{
Riana Susmayanti; Faculty of Law, University of Brawijaya; Jalan MT Haryono No. 169, Malang, \\ East Java, Indonesia; E-mail: riana.susma@ub.ac.id
}

\begin{abstract}
Abstrak
HOAX merupakan konsekuensi negatif dari penyelewengan kebebasan menyatakan pendapat. Hak menyatakan pendapat sebagai bagian dari hak kontitusional warga negara seharusnya dilaksanakan dengan penuh tanggung jawab. Namun UU Informasi dan Transaksi Elektronik membatasi pertanggungjawaban penyebaran HOAX dalam pasal-pasal saja. Oleh karena itu peneliti ingin melihat HOAX sebagai pelanggaran terhadap norma dan nilai dalam Pancasila, mengingat kedudukan Pancasila sebagai sumber dari segala sumber hukum. Penelitian yuridis normatif ini menganalisis dogmatik, teori dan fisafat hukum yang menunjukkan bahwa HOAX telah melanggar norma-norma dalam kelima sila Pancasila.
\end{abstract}

Kata Kunci: HOAX, Kebebasan Menyatakan Pendapat, Pancasila

\begin{abstract}
HOAX is a negative consequence of the abuse of freedom of speech. The freedom of speech as part of the citizens' constitutional rights should be exercised responsibly. However, the Act on Electronic Information and Transaction limits the responsibility for HOAX deployment in articles only. Therefore, researchers want to see HOAX as a violation of the norms and values in Pancasila, because of the position of Pancasila as the source of all sources of law. This normative juridical research analyzes dogmatic, theory and legal philosophy which shows that HOAX has violated the norms in the five Precepts of Pancasila.
\end{abstract}

Keywords: HOAX, Freedom of Speech, Pancasila

\section{INTRODUCTION}

\section{Background}

Man prefers to believe what he prefers to be true - Francis Bacon. ${ }^{1}$

Argentum ad Nausem (Big Lie) - Paul Joseph Goebbels. ${ }^{2}$

The idea of writing about "HOAX Versus Freedom Of Speech (In The Perspective Of Pancasila)" came after reflecting on my discussion with a student. The class had just ended that afternoon, but a female student was still staying in her chair and then came to me to the front of the class. "Ma' am, I am not a participant in this class, but I am interested in your subject." She was confused about her thesis. "How to determine the damaging effects of a hoax, ma'am? Is the number of hoaxes re-sharing on social media?" she asked. "The damaging effect on quality, not just how often the hoax is re-shared again. One hoax that is believed, is more damaging, than the hoax that is shared many times but no one believes. Try using Pancasila to assess the damaging effects of the hoax,"I replied. And that discussion sparked the idea on this research.

Humans are social creatures (zoon politicon) who need other humans to meet their needs, so that humans instinctively communicate and interact to gather with other

1 Goodreads, Man Prefers To Believe What He Prefers To Be True (online), https://www.goodreads.com/quotes/63465-man-prefers-to-believe-what-he-prefers-to-be-true (diakses 18 Mei 2020)

2 AR, 29 December 2016, Teori Goebbels Dalam Propaganda Jokowi (online), medium.com/@bintangmerah/teori-goebbels-dalam-propaganda-jokowi (accessed 20 May 2020) 
humans. ${ }^{3}$ Ideally, communication should be reciprocal and profitable. Where a person's rights and interests will always be limited by the rights and interests of others.

Freedom of speech is one of the personal rights inherent in a human being. ${ }^{4}$ In the 1945 Constitution, these human rights have secured a place as constitutional rights that are protected under Article 285 and Article 28 E paragraphs (2) and (3). ${ }^{6}$ The essence of the constitution is the manifestation of constitutionalism (understanding of the constitution), namely the limitation of government power, as well as guarantees of the rights of citizens and every resident.7 Along with development of technology, the media channeling the aspirations of citizens are also diverse increasingly. This is also supported by the 1945 Constitution, especially Article $28 \mathrm{C}$ paragraph (1) ${ }^{8}$, Article $28 \mathrm{~F}, 9$ and Article 31 paragraph (5). ${ }^{10}$

On the other hand, man prefers to believe what he prefers to be true. That is one of the famous quotes of Francis Bacon (1561-1626), a statesman, English writer, and philosopher who originated empiricism. ${ }^{11}$ If we think about Bacon's opinion, then the truth becomes relative ${ }^{12}$ and tentative ${ }^{13}$. Truth is not based on facts, but on which is more

${ }^{3}$ Article 28 E paragraph (3) Undang-Undang Dasar Negara Republik Indonesia Tahun 1945 (hereinafter referred to as The 1945 Constitution)

${ }^{4}$ Classification of human rights:

1. Personal rights: freedom to express opinions, embrace religion, etc.

2. Economic rights (property rights): the right to own something, use it, etc.

3. Human rights to get equal treatment in law and government (rights of legal equality)

4. Social and cultural rights: the right to choose education, etc.

5. Human rights to receive judicial procedures and protection (procedural rights).

Read: Darji Darmodiharjo dan Shidarta, Pokok-pokok Filsafat Hukum : Apa dan Bagaimana Filsafat Hukum Indonesia, PT Gramedia Pustaka Utama, Jakarta, 2002, p. 171.

${ }^{5}$ Article 28 of the 1945 Constitution: Freedom of association and assembly, expressing thoughts orally and in writing and so on is stipulated by law.

${ }^{6}$ Article 28 E paragraphs (3) and (4) of the 1945 Constitution:

(3) Everyone has the right to freedom of belief, to express thoughts and attitudes, according to his/ her conscience.

(4) Everyone has the right to freedom of association, assembly and expression.

7 Bagir Manan. (1995). Pertumbuhan dan Perkembangan Konstitusi Suatu Negara. Bandung: Mandar Maju, p. 6.

${ }^{8}$ Article 28 C paragraph (1) of the 1945 Constitution: Every person has the right to develop himself through the fulfillment of his basic needs, has the right to receive education and to benefit from science and technology, arts and culture, in order to improve his quality of life and for the welfare of mankind.

9 Article $28 \mathrm{~F}$ of the 1945 Constitution: Everyone has the right to communicate and obtain information to develop their personal and social environment, as well as the right to seek, obtain, possess, store, process and convey information using all available channels.

10 Article 31 paragraph (5) of the 1945 Constitution: The government shall advance science and technology by highly supporting religious values and national unity for the advancement of civilization and the welfare of mankind.

11 Britannica, Francis Bacon (online), https://www.britannica.com/biography/Francis-BaconViscount-Saint-Alban (diakses 19 Mei 2020)

12 Relatif adalah : tidak mutlak; nisbi. Baca : Kamus Besar Bahasa Indonesia (online), https://kbbi.web.id/relatif (diakses 20 Mei 2020) 
profitable and desirable. If 'something' is detrimental and undesirable, then that 'something' is not the truth despite the facts. Conversely, if it is profitable and as desired, then "it" is the truth, even though "it" is a lie which does not match the facts. Humans prefer to believe what he wants to be the truth, rather than the truth itself.

The idea is in line with Paul Joseph Goebbels (1897-1945), a Minister of Propaganda for the German Third Reich during the era of Adolf Hitler. As a master orator and propagandist, Big Lies according to Goebbels is a lie that is campaigned continuously and will systematically turn into (as if) reality. Whereas the perfect lie is the truth that is only slightly manipulated. ${ }^{14}$

These Bacon and Goebbels quotes are very suitable for current conditions, where information on social media can be shared wildly and is very easily considered as truth, without any need for clarification ${ }^{15}$ and proof. Even the lies (hoaxes) that are shared continuously are finally believed to be the truth, denying the essential facts.

Hoax is a negative impact and a logical consequence of unlimited freedom of speech. ${ }^{16}$ The sophistication of technology causes communication patterns to change from spoken and written to digital communication using social media. Social media has the power for bookmarking, content and sharing, connecting and creating opinions. ${ }^{17}$ Previously, the mainstream mass media were managed by formal press institutions with the supervision of ethics and legality of state law. On the other hand, social media made anyone can be a citizen journalist who independently searched for news and at the same time shared it. The real world has turned into a world-wide-web network, where citizens turn into netizens in a world without borders (stateless, borderless). This is where the legal conflict occurs.

Hoaxes have a certain appeal, because consciously or not, we all love to deceive other people. ${ }^{18}$ Hoax makers take advantage of people who fool others, and hoaxes have become a lifestyle. Truth is twisted, truth is contained in untruth, and untruth is truth. Hoax is truth, then truth is considered as hoax. Many observers have called this scary

${ }^{13}$ Tentatif adalah : 1 belum pasti; masih dapat berubah; 2 sementara waktu. Baca : Kamus Besar Bahasa Indonesia (online), https://kbbi.web.id/tentatif (diakses 20 Mei 2020)

14 Helmut Heiber, Joseph Goebbels, Encyclopædia Britannica (online), https:// www.britannica.com/biography/Joseph-Goebbels (diakses 20 Mei 2020)

15 Klarifikasi adalah: penjernihan, penjelasan, dan pengembalian kepada apa yang sebenarnya (tentang karya ilmiah dan sebagainya). Baca: Kamus Besar Bahasa Indonesia (online), https://kbbi.web.id/klarifikasi (diakses 20 Mei 2020)

16 Rosyida Irianti. (2018). Hoax dan Pergeseran Preferensi Sosial Politik Mahasiswa (Studi Deskriptif Mengenai Peran Ruang Publik dalam Masyarakat Urban). Skripsi. FISIP. Surabaya: Universitas Airlangga, p. 2.

${ }^{17}$ Aziz Bachtiar Cendekiawan. (2015). Efektivitas Penggunaan Sosial Media Twitter Sebagai Media Promosi Kesehatan (Analisis Epic Model pada follower Twitter @infoimunisasi PT Biofarma (Persero)). Skripsi. PS Ilmu Komunikasi, Fakultas Ilmu Sosial dan Humaniora. Yogyakarta: Universitas Islam Negeri Sultan Kalijaga, p. 12.

18 Gordon Stein dalam John George. (1994). Lies, Credulity, Ignorance, and More Lies. Jurnal Council for Democratic \& Secular Humanism Summer. 
phenomenon post-truth. ${ }^{19}$ The spread of hoaxes is easier because people tend to believe more in hoaxes if the information matches their opinion or attitude. ${ }^{20}$

Hoax is used by a person or group to influence the minds of others, and poisoning people's thoughts. ${ }^{21}$ A victim who is poisoned by hoax will never know that he is poisoned. Only the people around him who might know but cannot do much to help people who have been poisoned by the information. ${ }^{22}$

In this study, the contradiction between hoaxes and freedom of speech is analyzed based on the Pancasila ideology. Pancasila as the basis and ideology as a set of values and way of life for the Indonesia. This condition demands that the foundation and practice of national and state life must be based on the values contained in Pancasila. ${ }^{23}$

Before the circulation of hoaxes has too far affected the pattern of the nation's life in a negative direction, then we must return to the original foundation of the founding of a country, namely the philosophy of Pancasila. Pancasila can filter global impacts for national progress and prosperity. ${ }^{24}$ Therefore, researchers analyzed the circulation of hoaxes as violations of the principles of Pancasila.

\section{Legal Issue}

Based on the background described above, the legal issues in this research are:

a. What is the position of Pancasila as a parameter to assess the legal consequences of hoax circulation?

b. How is the circulation of hoaxes as a violation of the principles of Pancasila?

\section{METHODS}

As a scientific work, this research uses a method as an investigation that is carried out based on a specific plan to achieve a goal. The stages of this research are in the form of clear steps with certain restrictions to avoid getting lost and out of control. ${ }^{25}$

19 Fabianus Fensi. (2018). Fenomena Hoax: Tantangan Terhadap Idealisme Media \& Etika Bermedia, Bricolage Volume 4, Nomor 2, Tahun 2018: 133 - 209, p. 134.

20 S. Respati, 23 Januari 2017, Mengapa Banyak Orang Mudah Percaya Berita "Hoax"? http://nasional.kompas.com/read/2017/01/23/18181951/mengapa.banyak.orang.mud ah.percaya.berita.hoax. (diakses 7 September 2020)

${ }^{21}$ Arie Elcaputera dan Ari Wirya Dinata, Penegakan Hukum Penyebaran Berita Bohong (Hoax) Dalam Penyelenggaraan Pemilu 2019 Ditinjau dari Konsep Keadilan Pemilu, Call For Paper Evaluasi Pemilu Serentak 2019, Bidang Evaluasi Aspek Hukum Pemilu, www. Journal.kpu.go.id, p. 3 .

${ }^{22}$ H. Septanto. (2018). Pengaruh HOAX Dan Ujaran Kebencian Sebuah Cyber Crime dengan Teknologi Sederhana di Kehidupan Sosial Masyarakat, JurnalKalbiscentia, Volume 5, Nomor 2, Tahun 2018.

${ }^{23}$ Mardiyanto, 1 Jun 2019, Pancasila dan Tantangan Milenial, https://news.detik.com/kolom/d4573104/pancasila-dan-tantangan-milenial (diakses 7 September 2020)

${ }^{24}$ Suparman dalam Yolanda Hasian Ambarita, Jumat, 1 Jun 2018, Tekankan Nilai Pancasila untuk Tangkal Penyebaran Berita Hoax, https://www.bantennews.co.id/tekankan-nilai-pancasila-untuktangkal-penyebaran-berita-hoax/ (diakses 7 September 2020)

25 Johnny Ibrahim. (2013). Teori dan Metodologi Penelitian Hukum Normatif, Surabaya: Bayumedia Publishing, p. 294. 
Based on the legal issues described above, this research is designed as a normative study. This normative juridical research will analyze legal issues in 3 (three) domains, namely dogmatics, theory and philosophy. ${ }^{26}$ At the level of legal theory, the legal issue must contain legal concepts. This study analyzes the position of Pancasila as a parameter to assess the legal consequences of hoax circulation. Meanwhile, in the realm of legal philosophy, this study will analyze the circulation of hoaxes as violations of the principles of Pancasila.

In this normative juridical research, researchers use primary, secondary and tertiary legal materials to answer the formulation of problems in research. Primary legal materials are authoritative in nature, meaning they have authority, namely the 1945 Constitution. ${ }^{27}$ Furthermore, secondary legal materials include all publications on law (textbooks, law dictionaries and legal journals). This research topic intersects with communication science, so the use of non-legal books, especially communication science books, is also relevant. While tertiary legal materials include dictionaries, encyclopedias, mass media (print, electronic, online). The use of the dictionary is to clarify the definitions of various terms in this study, while the encyclopedia will provide insights on various things being studied.

The stage of tracing legal materials begins with determining the source of legal materials. Sources of legal materials are places where legal materials (primary, secondary, and tertiary) are found through library research in legal documentation and information centers, libraries and the internet.

Interpretation is also a method of legal discovery which provides an explanation of the text of the law so that the scope of the law can be determined in relation to certain events. ${ }^{28}$ The interpretation of the law arises because even though the law has been completely codified, it is still incomplete because there are things that have not been or are not clearly regulated so that it makes it difficult to implement the law. ${ }^{29}$

The legal materials collected will be inventoried, classified systematically, and analyzed based on a conceptual framework to conclude the definition of hoax. Interpretation methods are often used together or mixed up. Extensive and systematic interpretation will be carried out on the limitation of freedom of speech. ${ }^{30}$

Extensive interpretation (analogy) is a method of finding law, but it is also the creation of something new by expanding the meaning. ${ }^{31}$ Extensive interpretation is used

\footnotetext{
${ }^{26}$ Peter Mahmud Marzuki. (2011). Penelitian Hukum, Jakarta : Kencana, p. 65, 72, dan 77.

27 Ibid, p. 141.

28 B. Arief Sidharta dari DHM Meuwissen. (1994). Pengembanan Hukum. Majalah Pro Justitia Tahun XII Nomor 1 Januari 1994, Bandung: Fakultas Hukum Universitas Katholik Parahyangan, p. 63 dan 150.

${ }^{29}$ Samidjo dan A. Sahal. (1988). Tanya Jawab: Pengantar Ilmu Hukum. Bandung: Armico, p. 56

30 Sudikno Mertokusumo. (1996). Mengenal Hukum: Suatu Pengantar. Yogyakarta: Liberty Yogyakarta, p. 156.

${ }^{31}$ Lemaire dalam Ibid, p. 159.
} 
to make interpretations beyond the usual limits through grammatical interpretation, ${ }^{32}$ namely to expand the meaning of "hoax" in legislation.

Systematic or logical ${ }^{33}$ interpretations will be used to construct restrictions on freedom of expression in various laws. So the entire legislation in Indonesia is a complete system. ${ }^{34}$

\section{DISCUSSION}

\section{A. Pancasila As A Parameter to Assess The Legal Consequences of Hoax Circulation}

The position of Pancasila as the basis and ideology as well as the philosophical basis of the state has consequences for Pancasila as the source of all laws. The position is stated in the Fourth Paragraph of the Preamble of the 1945 Constitution, namely Beliefe in the One and Only God, Just and Civilized Humanity, Unity of Indonesia, Democracy led by Wisdom in Deliberation / Representation, and Social Justice for all Indonesian People. ${ }^{35}$

The position as the source of all laws ${ }^{36}$ means that Pancasila is a material source of law as well as a formal source of law. As a material source of law, it means that Pancasila is a source of law that determines the content of law, ${ }^{37}$ in the form of legal awareness that lives in society, ${ }^{38}$ which becomes a compromise ${ }^{39}$ (joint consensus) on what is considered good, correct, fair, and other ideal concepts. ${ }^{40}$ As a formal source of law, it means that Pancasila is a source of law that is known from its form ${ }^{41}$ and procedure, a place where law is found and recognized (in the form of laws, customs and traditions, jurisprudence, treaties and legal doctrine).42 Even though hoax actors have been threatened with punishment based on the Information and Electronic Transaction Law, the Press Law and the Broadcasting Law, the damaging effects of hoaxes should be filtered out by the values of Pancasila, which are believed to be the nation's way of life.

\footnotetext{
32 Ahmad Rifai. (2011). Penemuan Hukum oleh Hakim: Dalam Perspektif Hukum Progresif, Jakarta: Sinar Grafika, p. 70-71.

33 Tim Penyusun Hukum Acara Mahkamah Konstitusi. (2010). Hukum Acara Mahkamah Konstitusi. Jakarta: Sekretariat Jenderal dan Kepaniteraan MKRI, p. 72.

${ }^{34}$ Achmad Ali. (2002). Menguak Tabir Hukum (Suatu Kajian Filosofis dan Sosiologis). Jakarta: Toko Gunung Agung, p. 169.

${ }^{35}$ Paragraph 1 Elucidation of Article 2 of Law no. 12 of 2011 concerning the Establishment of Legislation

${ }^{36}$ Article 2 of Law no. 12 of 2011 concerning the Formation of Laws and Regulations in conjunction with Law no. 15 of 2019 concerning Amendments to Law Number 12 of 2011 concerning the Formation of Laws and Regulations

${ }^{37}$ Rozikin Daman. (1993). Hukum Tata Negara (Suatu Pengantar), Jakarta: Raja Grafindo Persada, p. 52.

${ }^{38}$ Samidjo. (1985). Pengantar Hukum Indonesia: Dalam Sistem S.K.S. dan Dilengkapi Satuan Acara Perkuliahan, Bandung: Armico, p. 37.

39 Ahmad Syafii Maarif. (2006). Islam dan Pancasila Sebagai Dasar Negara: Studi tentang Perdebatan dalam Konstituante. Jakarta: LP3ES, p. 148.

${ }^{40}$ Pancasila is a parameter, values that are contrary to Pancasila must not apply. Read : Moh. Kusnardi dan Harmaily Ibrahim. (1988). Hukum Tata Negara Indonesia. Jakarta: Pusat Studi Hukum Tata Negara FHUI dan Sinar Bakti, p. 46.

${ }^{41}$ Rozikin Daman, Op.Cit., p. 53.

${ }^{42}$ Samidjo, Op.Cit., p. 37-38.
} 


\section{B. Hoax Circulation As A Violation of Pancasila}

Pancasila contains 3 (three) main pillars, namely religious (pillars of divinity), humanistic (pillars of humanity), and pillars of society (democracy and social justice). This has made Pancasila become a national wisdom or national genius). ${ }^{43}$

Philosophical analysis of the legal consequences of hoaxes in terms of Pancasila is a discussion of ethics and legal morals in each of the precepts in Pancasila. Gordon Graham stated Eight Theories of Ethics are:44 1) egoism, 2) hedonism, 3) naturalism and virtue theory, 4) existentialism, 5) kantianism, 6) utilitarianism, 7) contractualism, and 8) religion. ${ }^{45}$

Pancasila is a whole philosophical system, ${ }^{46}$ so that the five precepts in Pancasila are an inseparable unit and each of these principles is connected logically. ${ }^{47}$ The five precepts in Pancasila are a philosophical system and organic unity, which are interconnected, related and qualifying. 48 The position of the Pancasila precepts is hierarchical-pyramidal which has a tiered sequence, that is, the preceding precepts become the basis for subsequent precepts. The following precepts become the specifics of the previous precepts. ${ }^{49}$ Belief in the One and Only God is the basis for humanity, Unity of Indonesia, democracy and justice. Belief in the One and Only God is a humanitarian deity that builds the unity of Indonesia, which is democratic and has social justice. ${ }^{50}$ Analyzed from the position of Pancasila as the legal language of the Indonesian nation, ${ }^{51}$ Pancasila as a parameter assesses the impact of hoax law not only in terms of terminology (words in the text), but is based on the spirit of kinship, protection, justice and truth that every Indonesian human lives.

\section{a. Hoax Circulation As A Violation Towards The First Precept of Pancasila}

The First Precept of Pancasila, "Belief in the One and Only God" reflects the divine values that Indonesia has as a religious state (a country that recognizes religion and belief, not just a specific religious state). As a philosophical teaching, Pancasila has reflected the

${ }^{43}$ Ganda Surya Satya JAP. (2013). Reaktualisasi Nilai-Nilai Pancasila (Core Values) sebagai Langkah Awal Reformasi Hukum Indonesia Berdasarkan Hukum Progresif, dalam Moh. Mahfud MD, dkk. Dekonstruksi dan Gerakan Pemikiran Hukum Progresif. Yogyakarta: Thafa Media, p. 246.

${ }^{44}$ Gordon Graham. (2015). Teori-Teori Etika (Eight Theories of Ethics). Bandung: Nusa Media, p. 233-251,

${ }^{45}$ One of the requirements to become a judge is religion. Baca: Sholeh So'an. (2004). Moral Penegak Hukum di Indonesia (Pengacara, Hakim, Polisi, Jaksa) dalam Pandangan Islam. Bandung: Agung Ilmu, p. 130.

46 Dardji Darmodihardjo, Aloysius R. Entah (Editor), Sekitar Pancasila, UUD '45, dan Pembangunan Sistem Hukum Indonesia. Malang: Surya Pena Gemilang, p. 20.

${ }^{47}$ Sunoto. (1995). Mengenal Filsafat Pancasila: Pendekatan melalui Metafisika, Logika dan Etika. Yogyakarta: PT Hanindita Graha Widya, p. 100.

48 Kaelan. (2002). Filsafat Pancasila: Pandangan Hidup Bangsa Indonesia. Yogyakarta: Paradigma, p. 66-67.

${ }^{49}$ Kaelan. (2010). Pendidikan Pancasila. Yogyakarta: Penerbit Paradigma, p. 57-61.

${ }^{50}$ Ibid., p. 68 Kaelan, Filsafat Pancasila.

${ }^{51}$ Nyana Wangsa dan Kristian. (2015). Hermeneutika Pancasila: Orisinaitas \& Bahasa Hukum Indonesia, Bandung: Refika Aditama, p. 91. 
fundamental and essential values and views of the Indonesian people in relation to the universal source, namely God the Creator. This divine principle is the fundamental principle in universality and is used as the fundamental principle of the state. ${ }^{52}$

The First Precept prioritizes the spiritualism aspect, not the materialism aspect, that is, every Indonesian citizen is obliged to have a religion, by prioritizing a religious attitude because life is not only looking for wealth and pleasure but there is a responsibility towards God, so before acting must think first whether it is in accordance with religious principles. This includes spreading uncertain news (hoaxes). ${ }^{53}$

Religious values as a source of ethics and spiritual behavior, including behavior and honesty in the virtual world. Respecting religious differences and beliefs in social media reflects tolerance in religious life. Not throwing insulting content or cornering certain religions and beliefs, will make peaceful religious life..$^{54}$

Unfortunately, hoaxes concerning religious issues are increasing, especially in political moments. ${ }^{55}$ Hoaxes in the name of religion are born from a mental attitude that overrides integrity, is aimed at manipulation, cheating, bringing down others, 56 triggering hostile conflicts over issues of ethnic, religious, racial and inter-group differences.

The use of this hoax is related to slander, manipulating place, space and time. Ironically, very few people check and re-check the correctness of this information, even the mainstream media also copy and paste from the internet and broadcast it. The following are some patterns of Hoax under the guise of religion:57

1) Famous figures converted to Islam (became mu'alaf), for example Paris Hilton, Robert Guilhem, and Demitry Bolikov. This hoax is used as a psychowar strategy, viewing religious preaching as a war, aimed at making religious followers feel victorious, proud and great. This type of hoax is intended to trick people into believing or accepting something that is fake and absurd, as genuine. Even though some of the characters mentioned are fictional.

2) The slaughter of the people of certain religion by another group. This hoax is intended to provoke emotions for jihad (fights), conflict, or to collect donations. In fact, that

52 Agus Rahardian dan I Putu Suyatra (Editor), 16 Juli 2020, Lawan Hoax dan Jaga Pancasila, https://baliexpress.jawapos.com/read/2020/07/16/204484/lawan-hoax-dan-jaga-pancasila (diakses 7 September 2020).

${ }^{53}$ Y. Latif, Negara Paripurna Historisitas dan Aktualitas Pancasila, Jakarta:Gramedia, 2011

${ }^{54}$ Mardiyanto, 1 Juni 2019, Pancasila dan Tantangan Milenial, https://news.detik.com/kolom/d4573104/pancasila-dan-tantangan-milenial (diakses 7 September 2020).

55 Masyarakat Anti Fitnah Indonesia (Mafindo) dalam Ibnu Hariyanto, 16 Oktober 2018, Anita Wahid: Hoax Makin Meningkat Bila Berhubungan dengan Isu Agama, https://news.detik.com/berita/d-4259224/anita-wahid-hoax-makin-meningkat-bilaberhubungan-dengan-isu-agama (diakses 7 September 2020).

56 Komarudin Hidayat, Bahaya Hoax Bisa Berujung Pada Pembunuhan Karakter, https://kominfo.go.id/content/detail/8716/bahaya-hoax-bisa-berujung-pada-pembunuhankarakter/0/sorotan_media (diakses 7 September 2020).

57 Martinov, 23 April 2013, Beberapa Peristiwa Hoax Berkedok Agama, https://www.kaskus.co.id/thread/5176091248ba54d34a000005/beberapa-peristiwa-hoaxberkedok-agama/. 
what happened was an effort to help evacuate victims of natural disasters, not massacres.

3) Black campaign against security forces who kill certain religious groups. Or distort the facts, turn the security forces into perpetrators of violence, while criminals become heroes. In fact, what happened was that the people lying down were still alive and the security forces secured the rioting demonstration.

4) The skin of a baby inscribed with verses in the Holy Qur'an. The fact is that the baby is suffering from dermatographic urticaria.

5) Members of other religions (who are seen as threats) are training in the military. The purpose of this type of hoax is internal consolidation by creating common enemies.

b. Hoax Circulation As A Violation Towards The Second Precept of Pancasila

The Second Precept, "Just and Civilized Humanity," contains the value of human empowerment so that they are not arbitrary towards nature and other living things. Every human being must have civility in every behavior in his social life and environment. Human values refer to respect for human values regardless of ethnicity, religion, race or class, so that public interests are placed above personal interests. 58

The Second Precept shows understanding and respect for the rights and obligations of everyone in cyberspace as a characteristic of humanist netizens. ${ }^{59}$ As a creature of God who has the same degree, human with dignity does not act arbitrarily towards other people in cyberspace. ${ }^{60}$ In connection with the Second Precept, hoaxes were created to cause wrong perceptions and conclusions, resulting in wrong attitudes, behaviors and actions. ${ }^{61}$ The act of spreading provocative hoax content is uncivilized.

\section{c. Hoax Circulation As A Violation Towards The Third Precept Of Pancasila}

The Third Precept, "Unity of Indonesia" summarizes Indonesia as a pluralistic nation due to the diversity of ethnicities, cultures, religions and languages that bind the Indonesian nation. Vertical plurality occurs due to differences in the level of education, wealth and position of Islam, while horizontal plurality comes from differences in ethnicity, religion and regionalism in Indonesia. ${ }^{62}$ A pluralistic nation must prioritize a sense of tolerance based on unity or form of Bhinneka Tunggal Ika (unity in diversity). ${ }^{63}$

${ }^{58}$ F. Fuad, Islam dan Ideologi Pancasila Sebuah Dialektika, Lex Jurnalica, Volume 9 Nomor 3 Tahun 2012.

${ }^{59}$ Mardiyanto, 1 Juni 2019, Pancasila dan Tantangan Milenial, https://news.detik.com/kolom/d4573104/pancasila-dan-tantangan-milenial (diakses 7 September 2020).

60 Yolanda Hasian Ambarita, Jumat, 1 Jun 2018, Tekankan Nilai Pancasila untuk Tangkal Penyebaran Berita Hoax, https:// www.bantennews.co.id/tekankan-nilai-pancasila-untuk-tangkalpenyebaran-berita-hoax/ (diakses 7 September 2020).

${ }^{61}$ Agus Rahardian dan I Putu Suyatra (Editor), 16 Juli 2020, Lawan Hoax dan Jaga Pancasila, https:// baliexpress.jawapos.com/read/2020/07/16/204484/lawan-hoax-dan-jaga-pancasila (diakses 7 September 2020).

${ }^{62}$ Achmad Fedyani Syaifuddin. (2006). Membumikan Multikulturalisme di Indonesia. .Jurnal Antropologi Sosial Budaya ETNOVISI. Vol 2, No 1 Tahun 2006.

${ }^{63}$ Dewi Oktaviani Hidayat, Inggi Eltarian, Oktralika, Rahmat Kevin Priyatna, Sindi Agustina Fernanda, Pendidikan Pancasila dan Kewarganegaraan, Universitas Lampung, Implementasi 
The principle of unity in difference shows the uniqueness of Pancasila as an ideology for a country that has diversity. Ideal unity means that every citizen lives side by side and works together without losing ethnic identity, customs, race, or religion. ${ }^{64}$

This Third Precept contains the meaning of unity which aims to unite the various ethnic groups, religions, races and customs in Indonesia. This value of unity reflects the virtual world as a medium to strengthen the spirit of nationalism and diversity. During online discussions on social media, prioritizing national unity and integrity above group or personal interests and upholding unity in diversity in every difference. 65

\section{d. Hoax Circulation As A Violation Towards The Fouth Precept Of Pancasila}

The Fourth Precept "Democracy led by Wisdom in Deliberation / Representation" shows a wise and polite attitude towards differences in political views in cyberspace, participates in carrying out any decisions made through online discussions, and resolves any debates in online groups by promoting deliberation. 66

The Fourth Precept contains the meaning of preventing misunderstandings and individualistic tendencies that can lead to conflict on racial issues due to the circulation of hoaxes. Citizens must work together in order to be able to create a peace and welfare of the nation. A democratic system means that the deliberation process does not only prioritize the voice of the people but also prioritizes the rule of law. Everything that is deemed to be detrimental to others will be processed by the law, including the circulation of hoaxes. ${ }^{67}$

The spread of hoaxes as political propaganda increased during the election campaign period.68 Although criticized, propaganda techniques are widely used by candidates or politicians as political communicators. Hoax is a powerful stance for assassinating the character of political opponents, because its rapid and massive spread through social media can influence people in determining their political choices. ${ }^{69}$

Hoaxes in this type are falsehoods deliberately created to disguise themselves as truth, to irresponsibly change people's political perspectives and preferences, and to

Nilai-Nilai Pancasila Dalam Mencegah Degradasi Moral Terhadap Isu Sara Dan Hoax, Jurnal Rontal Keilmuan PKN Vol. 5/No. 1/April 2019

${ }^{64}$ Mardiyanto, 1 Juni 2019, Pancasila dan Tantangan Milenial, https://news.detik.com/kolom/d4573104/pancasila-dan-tantangan-milenial (diakses 7 September 2020)

${ }^{65}$ Mardiyanto, 1 Juni 2019, Pancasila dan Tantangan Milenial, https://news.detik.com/ kolom/d4573104/pancasila-dan-tantangan-milenial (diakses 7 September 2020)

${ }^{66}$ Mardiyanto, 1 Juni 2019, Pancasila dan Tantangan Milenial, https://news.detik.com/kolom/d4573104/pancasila-dan-tantangan-milenial (diakses 7 September 2020)

67 B. Maftuh, Internalisasi Nilai-Nilai Pancasila dan Nasionalisme Melalui Pendidikan Kewarganegaraan, Jurnal Educationist, Volume 2 Nomor 2 Tahun 2008

${ }^{68}$ Utami dalam Arie Elcaputera dan Ari Wirya Dinata, Penegakan Hukum Penyebaran Berita Bohong (Hoax) Dalam Penyelenggaraan Pemilu 2019 Ditinjau Dari Konsep Keadilan Pemilu, Call For Paper Evaluasi Pemilu Serentak 2019, Bidang Evaluasi Aspek Hukum Pemilu, www. Journal.kpu.go.id, p. 3

${ }^{69}$ Arie Elcaputera dan Ari Wirya Dinata, Penegakan Hukum Penyebaran Berita Bohong (Hoax) Dalam Penyelenggaraan Pemilu 2019 Ditinjau Dari Konsep Keadilan Pemilu, Call For Paper Evaluasi Pemilu Serentak 2019, Bidang Evaluasi Aspek Hukum Pemilu, www. Journal.kpu.go.id, p. 2 
damage an election administration by committing fraud. ${ }^{70}$ Hoaxes are deliberately designed to influence or provoke actions in accordance with the interests of those who create information. ${ }^{71}$

The negative impacts of hoaxes that may arise include:72 1) damaging the credibility and integrity of general election institution; 2) damages the credibility and integrity of politicians who compete in general elections; 3) causing unrest or uproar in the community; and 4) dividing the unity and integrity of the nation. Associated with the values in the Fourth Precept, hoaxes destroy democracy, so that people cannot make wise choices in the representation mechanism, conflicts that arise will make it impossible for deliberation to reach consensus.

The spread of hoaxes has the potential to spark conflict between groups and a crisis of trust that threatens the quality of Indonesian democracy in the future. ${ }^{73}$ Hoaxes circulating during the election have proven successful in sending waves of hatred,74 marked by virtual wars between supporters of candidate pairs in cyberspace, but ultimately impacting on threats to the integrity of the nation.

\section{e. Hoax Circulation As A Violation Towards The Fifth Precept Of Pancasila}

The Fifth Precept "Social Justice for All Indonesians" reflects the values of social justice, that everyone has the same rights and obligations to access information and gather in cyber groups while respecting the human rights of everyone. ${ }^{75}$

The fifth precept contains the meaning of policies that can be enjoyed and appreciated by all Indonesian people. Every citizen is able to make decisions that are fair to every citizen without discrimination. ${ }^{76}$

\section{CONCLUSION}

The circulation of hoaxes is not only sufficiently analyzed using statutory regulations. The phenomenon of hoaxes as a lifestyle that poison netizens in the millennial era must be studied based on the values of Pancasila. Agreed as the national identity, Pancasila also recognized as an ideology, philosophy and code of conduct should be a filter for

\footnotetext{
${ }^{70}$ Curtis D Macdougall dalam Ibid, $p .3$

${ }^{71}$ Kusman dalam Ibid.

${ }^{72}$ Arie Elcaputera dan Ari Wirya Dinata, Penegakan Hukum Penyebaran Berita Bohong (Hoax) Dalam Penyelenggaraan Pemilu 2019 Ditinjau Dari Konsep Keadilan Pemilu, Call For Paper Evaluasi Pemilu Serentak 2019, Bidang Evaluasi Aspek Hukum Pemilu, www. Journal.kpu.go.id, p. 12.

73 Yolanda Hasian Ambarita, Jumat, 1 Jun 2018, Tekankan Nilai Pancasila untuk Tangkal Penyebaran Berita Hoax, https://www.bantennews.co.id/tekankan-nilai-pancasila-untuk-tangkalpenyebaran-berita-hoax/ (diakses 7 September 2020)

${ }_{74}$ M. Iqbal Al Machmudi, 12 November 2019, Menangkal Hoaks Melalui Nilai-Nilai Pancasila, https://mediaindonesia.com/read/detail/270926-menangkal-hoaks-melalui-nilai-nilai-pancasila (diakses 7 September 2020)

${ }^{75}$ Mardiyanto, 1 Juni 2019, Pancasila dan Tantangan Milenial, https://news.detik.com/kolom/d4573104/pancasila-dan-tantangan-milenial (diakses 7 September 2020)

${ }^{76}$ Damanhuri. (2016). Implementasi NilaiNilai Pancasila Sebagai Upaya Pembangunan Karakter Bangsa. Jurnal Untirta Civic Education, Vol. 1, No. 02, Tahun 2016
} 
negative excesses from the spread of hoaxes. The circulation of hoaxes has violated religious values, honesty, ignoring the fear of God, because of the loss of awareness of responsibility in using social media. The circulation of hoaxes has also violated human values, the loss of humanist behavior in cyberspace. This removes the value of unity as it exacerbates differences. The circulation of hoaxes has also violated democracy and democratic values. It is proven from the data on hoax circulation that has increased during the general election campaign.

The importance of the position of Pancasila in the Preamble of the 1945 Constitution, should be followed by many studies on Pancasila from various aspects. The study is not to look for the weaknesses of Pancasila as an ideology, but to revive a sense of citizen ownership towards Pancasila. Pancasila is not only memorized and read during ceremonies, but becomes a guideline in real life and surfing in cyberspace.

\section{REFERENCES}

Achmad Ali. (2002). Menguak Tabir Hukum (Suatu Kajian Filosofis dan Sosiologis), Jakarta: Toko Gunung Agung.

Achmad Fedyani Syaifuddin. (2006). "Membumikan Multikulturalisme di Indonesia", Jurnal Antropologi Sosial Budaya ETNOVISI. Vol 2, No 1 Tahun 2006.

Agus Rahardian dan I Putu Suyatra (Editor), 16 Juli 2020, Lawan Hoax dan Jaga Pancasila, https://baliexpress.jawapos.com/read/2020/07/16/204484/lawan-hoaxdan-jaga-pancasila (diakses 7 September 2020).

Ahmad Rifai. (2011). Penemuan Hukum oleh Hakim: Dalam Perspektif Hukum Progresif, Jakarta: Sinar Grafika.

Ahmad Syafii Maarif. (2006). Islam dan Pancasila Sebagai Dasar Negara: Studi tentang Perdebatan dalam Konstituante. Jakarta: LP3ES.

AR, 29 December 2016, Teori Goebbels dalam Propaganda Jokowi (online), medium.com/@bintangmerah/teori-goebbels-dalam-propaganda-jokowi (accessed 20 May 2020).

Arie Elcaputera dan Ari Wirya Dinata, Penegakan Hukum Penyebaran Berita Bohong (Hoax) dalam Penyelenggaraan Pemilu 2019 Ditinjau dari Konsep Keadilan Pemilu, Call For Paper Evaluasi Pemilu Serentak 2019, Bidang Evaluasi Aspek Hukum Pemilu, www. Journal.kpu.go.id.

Aziz Bachtiar Cendekiawan. (2015). Efektivitas Penggunaan Sosial Media Twitter Sebagai Media Promosi Kesehatan (Analisis Epic Model pada follower Twitter @infoimunisasi PT Biofarma (Persero). Skripsi. Yogyakarta: PS Ilmu Komunikasi, Fakultas Ilmu Sosial dan Humaniora, Universitas Islam Negeri Sultan Kalijaga.

B. Arief Sidharta dari DHM Meuwissen. (1994). "Pengembanan Hukum", Majalah Pro Justitia Tahun XII Nomor 1 Januari 1994. Bandung: Fakultas Hukum Universitas Katholik Parahyangan.

B. Maftuh. (2008). “Internalisasi Nilai-Nilai Pancasila dan Nasionalisme Melalui Pendidikan Kewarganegaraan”. Jurnal Educationist, Volume 2 Nomor 2 Tahun 2008. 
Bagir Manan. (1995). Pertumbuhan dan Perkembangan Konstitusi Suatu Negara, Bandung: Mandar Maju.

Britannica, Francis Bacon (online), https://www.britannica.com/biography/FrancisBacon-Viscount-Saint-Alban (diakses 19 Mei 2020)

Damanhuri. (2016). "Implementasi NilaiNilai Pancasila Sebagai Upaya Pembangunan Karakter Bangsa”. Jurnal Untirta Civic Education, Vol. 1, No. 02, Tahun 2016.

Dardji Darmodihardjo, Aloysius R. Entah (Editor). Sekitar Pancasila, UUD '45, dan

Pembangunan Sistem Hukum Indonesia. Malang: Surya Pena Gemilang.

Darji Darmodiharjo dan Shidarta. (2002). Pokok-Pokok Filsafat Hukum: Apa dan Bagaimana Filsafat Hukum Indonesia. Jakarta: PT Gramedia Pustaka Utama.

Dewi Oktaviani Hidayat, Inggi Eltarian, Oktralika, Rahmat Kevin Priyatna, Sindi Agustina Fernanda. (2019). Pendidikan Pancasila dan Kewarganegaraan, Universitas Lampung, "Implementasi Nilai-Nilai Pancasila dalam Mencegah Degradasi Moral Terhadap Isu Sara Dan Hoax", Jurnal Rontal Keilmuan PKN Vol. 5/No. 1/April 2019.

F. Fuad. (2012). "Islam dan Ideologi Pancasila Sebuah Dialektika". Lex Jurnalica, Volume 9 Nomor 3 Tahun 2012.

Fabianus Fensi. (2018). "Fenomena Hoax: Tantangan Terhadap Idealisme Media \& Etika Bermedia”, Bricolage Volume 4, Nomor 2, Tahun 2018.

Ganda Surya Satya JAP, Reaktualisasi Nilai-Nilai Pancasila (Core Values) Sebagai Langkah Awal Reformasi Hukum Indonesia Berdasarkan Hukum Progresif, dalam Moh. Mahfud MD, dkk. (2013). Dekonstruksi dan Gerakan Pemikiran Hukum Progresif. Yogyakarta : Thafa Media.

Goodreads, Man Prefers To Believe What He Prefers To Be True (online), https://www.goodreads.com/quotes/63465-man-prefers-to-believe-what-heprefers-to-be-true (diakses 18 Mei 2020)

Gordon Graham. (2015). Teori-Teori Etika (Eight Theories of Ethics), (Bandung : Nusa Media,

Gordon Stein dalam John George. (1994). "Lies, Credulity, Ignorance, and More Lies", Jurnal Council for Democratic \& Secular Humanism Summer.

H. Septanto. (2018). Pengaruh HOAX dan Ujaran Kebencian Sebuah Cyber Crime dengan Teknologi Sederhana di Kehidupan Sosial Masyarakat, JurnalKalbiscentia, Volume 5, Nomor 2, Tahun 2018.

Helmut Heiber, Joseph Goebbels, Encyclopædia Britannica (online), https://www.britannica.com/biography/Joseph-Goebbels (diakses 20 Mei 2020)

Johnny Ibrahim. (2013). Teori dan Metodologi Penelitian Hukum Normatif. Surabaya: Bayumedia Publishing.

Kaelan. (2002). Filsafat Pancasila: Pandangan Hidup Bangsa Indonesia. Yogyakarta: Paradigma.

Kaelan. (2010). Pendidikan Pancasila. Yogyakarta: Penerbit Paradigma.

Kamus Besar Bahasa Indonesia (online), https://kbbi.web.id/klarifikasi (diakses 20 Mei 2020) 
Komarudin Hidayat, Bahaya Hoax Bisa Berujung Pada Pembunuhan Karakter, https://kominfo.go.id/content/detail/8716/bahaya-hoax-bisa-berujung-padapembunuhan-karakter/0/sorotan_media (diakses 7 September 2020)

M. Iqbal Al Machmudi, 12 November 2019, Menangkal Hoaks Melalui Nilai-Nilai Pancasila, https://mediaindonesia.com/read/detail/270926-menangkal-hoaksmelalui-nilai-nilai-pancasila (diakses 7 September 2020)

Mardiyanto, 1 Jun 2019, Pancasila dan Tantangan Milenial, https://news.detik.com/kolom/d-4573104/pancasila-dan-tantangan-milenial (diakses 7 September 2020)

Martinov, 23 April 2013, Beberapa Peristiwa Hoax Berkedok Agama, https://www.kaskus.co.id/thread/5176091248ba54d34a000005/beberapa-peristiwahoax-berkedok-agama/

Masyarakat Anti Fitnah Indonesia (Mafindo) dalam Ibnu Hariyanto, 16 Oktober 2018, Anita Wahid: Hoax Makin Meningkat Bila Berhubungan dengan Isu Agama, https://news.detik.com/berita/d-4259224/anita-wahid-hoax-makin-meningkat-bilaberhubungan-dengan-isu-agama (diakses 7 September 2020)

Moh. Kusnardi dan Harmaily Ibrahim. (1988). Hukum Tata Negara Indonesia. Jakarta: Pusat Studi Hukum Tata Negara FHUI dan Sinar Bakti.

Nyana Wangsa dan Kristian. (2015). Hermeneutika Pancasila: Orisinaitas \& Bahasa Hukum Indonesia. Bandung: Refika Aditama.

Peter Mahmud Marzuki. (2011). Penelitian Hukum. Jakarta: Kencana.

Rosyida Irianti. (2018). Hoax dan Pergeseran Preferensi Sosial Politik Mahasiswa (Studi Deskriptif Mengenai Peran Ruang Publik dalam Masyarakat Urban. Skripsi. Surabaya: FISIP, Universitas Airlangga.

Rozikin Daman, Hukum Tata Negara (Suatu Pengantar), (Jakarta : RajaGrafindo Persada, 1993)

S. Respati, 23 Januari 2017, Mengapa Banyak Orang Mudah Percaya Berita "Hoax"? http://nasional.kompas.com/read/2017/01/23/18181951/mengapa.banya k.orang.mudah.percaya.berita.hoax. (diakses 7 September 2020)

Samidjo dan A. Sahal. (1988). Tanya Jawab: Pengantar Ilmu Hukum. Bandung : Armico. Samidjo. (1985). Pengantar Hukum Indonesia: Dalam Sistem S.K.S. dan Dilengkapi Satuan Acara Perkuliahan. Bandung: Armico.

Sholeh So'an. (2004). Moral Penegak Hukum di Indonesia (Pengacara, Hakim, Polisi, Jaksa) dalam Pandangan Islam. Bandung: Agung Ilmu.

Sudikno Mertokusumo. (1996). Mengenal Hukum: Suatu Pengantar. Yogyakarta: Liberty Sunoto. (1995). Mengenal Filsafat Pancasila: Pendekatan melalui Metafisika, Logika dan Etika. Yogyakarta: PT Hanindita Graha Widya.

Suparman dalam Yolanda Hasian Ambarita, Jumat, 1 Jun 2018, Tekankan Nilai Pancasila untuk Tangkal Penyebaran Berita Hoax, https://www.bantennews.co.id/tekankannilai-pancasila-untuk-tangkal-penyebaran-berita-hoax/ (diakses 7 September 2020)

Tim Penyusun Hukum Acara Mahkamah Konstitusi. (2010). Hukum Acara Mahkamah Konstitusi. Jakarta : Sekretariat Jenderal dan Kepaniteraan MKRI. 
Utami dalam Arie Elcaputera dan Ari Wirya Dinata. Penegakan Hukum Penyebaran Berita Bohong (Hoax) dalam Penyelenggaraan Pemilu 2019 Ditinjau Dari Konsep Keadilan Pemilu, Call For Paper Evaluasi Pemilu Serentak 2019, Bidang Evaluasi Aspek Hukum Pemilu, www. Journal.kpu.go.id

Y. Latif. (2011). Negara Paripurna Historisitas dan Aktualitas Pancasila. Jakarta: Gramedia.

Yolanda Hasian Ambarita, Jumat, 1 Jun 2018, Tekankan Nilai Pancasila untuk Tangkal Penyebaran Berita Hoax, https://www.bantennews.co.id/tekankan-nilai-pancasilauntuk-tangkal-penyebaran-berita-hoax/ (diakses 7 September 2020) 